\title{
Sheep production as a Senecio spp. control tool ${ }^{1}$
}

\author{
Paulo Mota Bandarra², Luiz Gustavo de Oliveira², André Cabrera Dalto², Fabiana \\ Marques Boabaid ${ }^{2}$, Gregory Juffo ${ }^{2}$, Franklin Riet-Correa ${ }^{3}$, David Driemeier ${ }^{2}$ \\ and Cláudio Estêvão Farias da Cruz ${ }^{2 *}$
}

\begin{abstract}
Bandarra P.M., Oliveira L.G., Dalto A.G., Boabaid F.M., Juffo G., Riet-Correa F., Driemeier D. \& Cruz C.E.F. 2012. Sheep production as a Senecio spp. control tool. Pesquisa Veterinária Brasileira 32(10):1017-1022. Setor de Patologia Veterinária, Faculdade de Veterinária, Universidade Federal do Rio Grande do Sul, Av. Bento Gonçalves 9090, Porto Alegre, RS 91540-000, Brazil. E-mail: claudio.cruz@ufrgs.br

Since poisoning by Senecio spp. is one of the main causes of cattle death in southern Brazil, control of these plants is a priority for the local livestock production. After the pasture has been mowed, grazing by 16 sheep was efficient for controlling Senecio brasiliensis and Senecio madagascariensis populations in a 5.5-hectare area that had long been severely infested with these species. A total of 28,629 plants among S. brasiliensis (flower-of-souls, 10,122 ) and $S$. madagascariensis (fireweed, 18,507) were almost completely eliminated in a two-year period. The number of sheep was kept at 3.0 stock units/ha, but a variable number of cattle were temporarily stocked according to pasture availability. The major sanitary practice applied to the sheep was anthelmintic administration. Liver biopsies taken from sheep and cattle before and after experimental period didn't reveal any change associable with seneciosis. The performance levels of the sheep were comparable to those observed in flocks managed under traditional extensive grazing systems in southern Brazil.
\end{abstract}

INDEX TERMS: Senecio brasiliensis, Senecio madagascariensis, control, sheep grazing, sheep performance.

RESUMO.- [Ovinocultura, ferramenta de controle de Senecio spp.] As intoxicações por Senecio spp. estão entre as principais causas de morte de bovinos no sul do Brasil; portanto, o controle dessas plantas é prioridade para a pecuária local. Depois de uma roçada, o pastejo por 16 ovinos controlou, eficientemente, populações de Senecio brasiliensis e Senecio madagascariensis em uma área de 5,5 hectares, a qual havia se mantido, por oito anos consecutivos, severamente, infestada por essas espécies. Um total de 28.629 plantas, entre $S$. brasiliensis (10.122) e $S$. madagascariensis (18.507) foi, virtualmente, eliminado em um período de dois anos. 0 número de ovelhas foi mantido em três unidades / hectare, mas variáveis lotações de bovinos foram associadas com a disponibilidade de forragem.

\footnotetext{
${ }^{1}$ Received on May 31, 2012.

Accepted for publication on July 11, 2012

${ }^{2}$ Departamento de Patologia Clínica Veterinária, Faculdade de Veterinária, Universidade Federal do Rio Grande do Sul (UFRGS), Avenida Bento Gonçalves 9090, Porto Alegre, RS 91540-000, Brazil. *Corresponding author: claudio.cruz@ufrgs.br

${ }^{3}$ Centro de Saúde e Tecnologia Rural, Universidade Federal de Campina Grande (UFCG), Avenida Universitária s/n, Patos, PB 58708-110, Brazil.
}

As principais práticas de manejo sanitário aplicadas aos ovinos foram administrações de anti-helmínticos. Biópsias hepáticas, colhidas antes e após o período de estudo, não revelaram qualquer alteração associável com seneciose. Os níveis de desempenho dos ovinos foram comparáveis aos observados em rebanhos manejados em sistemas extensivos tradicionais no sul do Brasil.

TERMOS DE INDEXAÇÃO: Senecio brasiliensis, Senecio madagascariensis, controle, pastejo, desempenho, ovinos.

\section{INTRODUCTION}

Of more than 1,200 worldwide species of Senecio, approximately 25 have been demonstrated to be toxic to livestock. The clinical, pathological, and epidemiological features associated with poisoning by different Senecio species are usually quite similar (Tokarnia et al. 2012). Senecio madagascariensis (fireweed), a species native to southern Africa (Scott et al. 1998), has been introduced in Australia (Parsons \& Cuthbertson 2001), Hawaii (Roux et al. 2006), Argentina (Villalba \& Fernández 2005), Brazil (Matzenbacher \& Schneider 2008), and possibly many other countries. The 
toxic potential to livestock grazing heavily $S$. madagascariensis-infested rangelands has been recorded (Gardner et al. 2006, Cruz et al. 2010). Moreover, fireweed's invasive potential sufficiently justifies any applicable control measure.

Senecio brasiliensis (flower-of-souls) is the most frequent cause of the Brazilian outbreaks of pyrrolizidine alkaloid poisoning in livestock (Barros et al. 2007, Tokarnia et al. 2012). Controlling incidents of seneciosis is a priority for local agriculture because of the disease's high prevalence in southern Brazil, its high lethality, the irreversible character of the hepatic lesions in the sufferer, and the heavy economic losses associated with the disease (Tokarnia et al. 2012, Riet-Correa \& Méndez 2007). Due to the debilitating nature of bovine seneciosis, the control measures must focus on the prevention of weed consumption by cattle. Due to the hepatic detoxification mechanisms associated with the adaptation of the ruminal flora (Kellerman et al. 1995, Cheeke 1994), sheep might ingest and control Senecio spp. populations with a minimal risk of poisoning. However, there has been little research either documenting the applicable methods for this proposal or recording the performance of sheep flocks managed on Senecio-infested pastures. This paper reports the results of a 2-year study on the performance of a small sheep flock managed to control Senecio spp. by grazing.

\section{MATERIALS AND METHODS}

\section{General procedures and sheep facilities}

The study was performed on a beef cattle farm in which the herd had suffered numerous losses due to Senecio spp. consumption. A 7-wire sheep fence was constructed around a 5.5-hectare (ha) area that had been severely infested by $S$. brasiliensis and $S$. madagascariensis populations for more than 8 consecutive years. A shade refuge and drinking water were provided. The sheep's mineral blocks were provided on a regular basis. A simplified sheep corral unit was installed at a corner of the paddock. The predominant forage species present in the area were identified, and pasture mass was estimated with the clipping and weighing method.

\section{Level of Senecio spp. infestation}

To count the Senecio plants, the total area (5.5 ha) was divided into 20 similar parcels of 3,000 $\mathrm{m}^{2}$. In each parcel, one person counted the $S$. brasiliensis plants, while another person counted the S. madagascariensis plants. Samples of the Senecio plants were weighed. In 2010 and 2011, the level of Senecio spp. persistence was estimated by a quarterly counting of the emergent seedlings from the five most Senecio-infested parcels of the 20 parcels in the 5.5 ha area. Also, the level of $S$. brasiliensis infestation was estimated by examining aerial pictures taken annually at the flowering $S$. brasiliensis stage (October).

\section{Management and controls}

In late November, 2009, after the $S$. brasiliensis drying stage and seedling dispersal, all the pastures in the area were trimmed to $20-\mathrm{cm}$ high by a mower. Subsequently, experimental $(16$ sheep) and control (11 sheep) groups were introduced in the infested area and in a 3.6-ha Senecio-free paddock, respectively. Sheep were continuously kept at 3.0 stock units/ha in both areas. The sheep were mixed Texel/Corriedale, 4-6 years of age. Basic sanitary measures were practiced. A general observation of the groups was performed daily by farm personnel. A 30-60 minute observation of sheep grazing behavior was conducted monthly just before an application of the sanitary practices. Sheep pregnancies were identified and controlled by ultrasonography, and lamb weight gains were recorded monthly for the first 5 months of age. She-

Table 1. Level of Senecio spp. infestation in a 5.5-hectare area and in a $2700 \mathrm{~m}^{2}$ control area. Total plant counting, November 2009. Estimates of seedling counting in quadrants, 2010 to 2011

\begin{tabular}{|c|c|c|c|c|c|c|c|c|c|c|c|c|c|c|}
\hline \multirow[t]{3}{*}{ Parcels } & \multicolumn{2}{|c|}{2009} & \multicolumn{6}{|c|}{2010} & \multicolumn{6}{|c|}{2011} \\
\hline & \multirow[t]{2}{*}{ S. m } & \multirow[t]{2}{*}{ S. b } & \multicolumn{2}{|c|}{ JUN } & \multicolumn{2}{|c|}{ AUG } & \multicolumn{2}{|c|}{ OCT } & \multicolumn{2}{|c|}{ JUN } & \multicolumn{2}{|c|}{ AUG } & \multicolumn{2}{|c|}{ OCT } \\
\hline & & & S. m & S.b & S. m & S. b & S. m & S. b & S. m & S. b & S. $\mathrm{m}$ & S.b & S. m & S. b \\
\hline 1 & 38 & 6 & & & & & & & & & & & & \\
\hline 2 & 142 & 13 & & & & & & & & & & & & \\
\hline 3 & 382 & 48 & & & & & & & & & & & & \\
\hline 4 & 33 & 143 & & & & & & & & & & & & \\
\hline 5 & 296 & 21 & & & & & & & & & & & & \\
\hline 6 & 214 & 298 & & & & & & & & & & & & \\
\hline 7 & 76 & 252 & & & & & & & & & & & & \\
\hline 8 & 361 & 489 & & & & & & & & & & & & \\
\hline 9 & 564 & 230 & & & & & & & & & & & & \\
\hline 10 & 1894 & 168 & & & & & & & & & & & & \\
\hline 11 & 2661 & 3 & & & & & & & & & & & & \\
\hline 12 & 49 & 395 & & & & & & & & & & & & \\
\hline 13 & 1024 & 598 & 85 & 57 & 15 & 5 & 1 & 0 & 0 & 3 & 0 & 0 & 0 & 0 \\
\hline 14 & 660 & 547 & & & & & & & & & & & & \\
\hline 15 & 2558 & 1372 & 292 & 187 & 29 & 6 & 2 & 0 & 0 & 4 & 0 & 1 & 0 & 1 \\
\hline 16 & 2445 & 654 & 321 & 43 & 28 & 11 & 0 & 0 & 0 & 1 & 0 & 0 & 0 & 0 \\
\hline 17 & 1658 & 2159 & 125 & 313 & 102 & 7 & 3 & 3 & 0 & 8 & 0 & 2 & 0 & 2 \\
\hline 18 & 3452 & 0 & 443 & 126 & 24 & 0 & 3 & 0 & 0 & 0 & 0 & 0 & 0 & 0 \\
\hline 19 & 0 & 681 & & & & & & & & & & & & \\
\hline 20 & 0 & 2025 & & & & & & & & & & & & \\
\hline Total & 18507 & 10102 & 1266 & 726 & 198 & 29 & 9 & 3 & 0 & 16 & 0 & 3 & $\mathbf{0}$ & 3 \\
\hline $\mathrm{Ca}$ & 84 & 112 & 35 & 58 & 59 & 76 & 92 & 81 & 101 & 139 & 101 & 135 & 100 & 126 \\
\hline
\end{tabular}

$\overline{\mathrm{S} . \mathrm{m}}=$ Senecio madagascariensis, $\mathrm{S} . \mathrm{b}=$ Senecio brasiliensis, $\mathrm{Ca}=$ control area . 

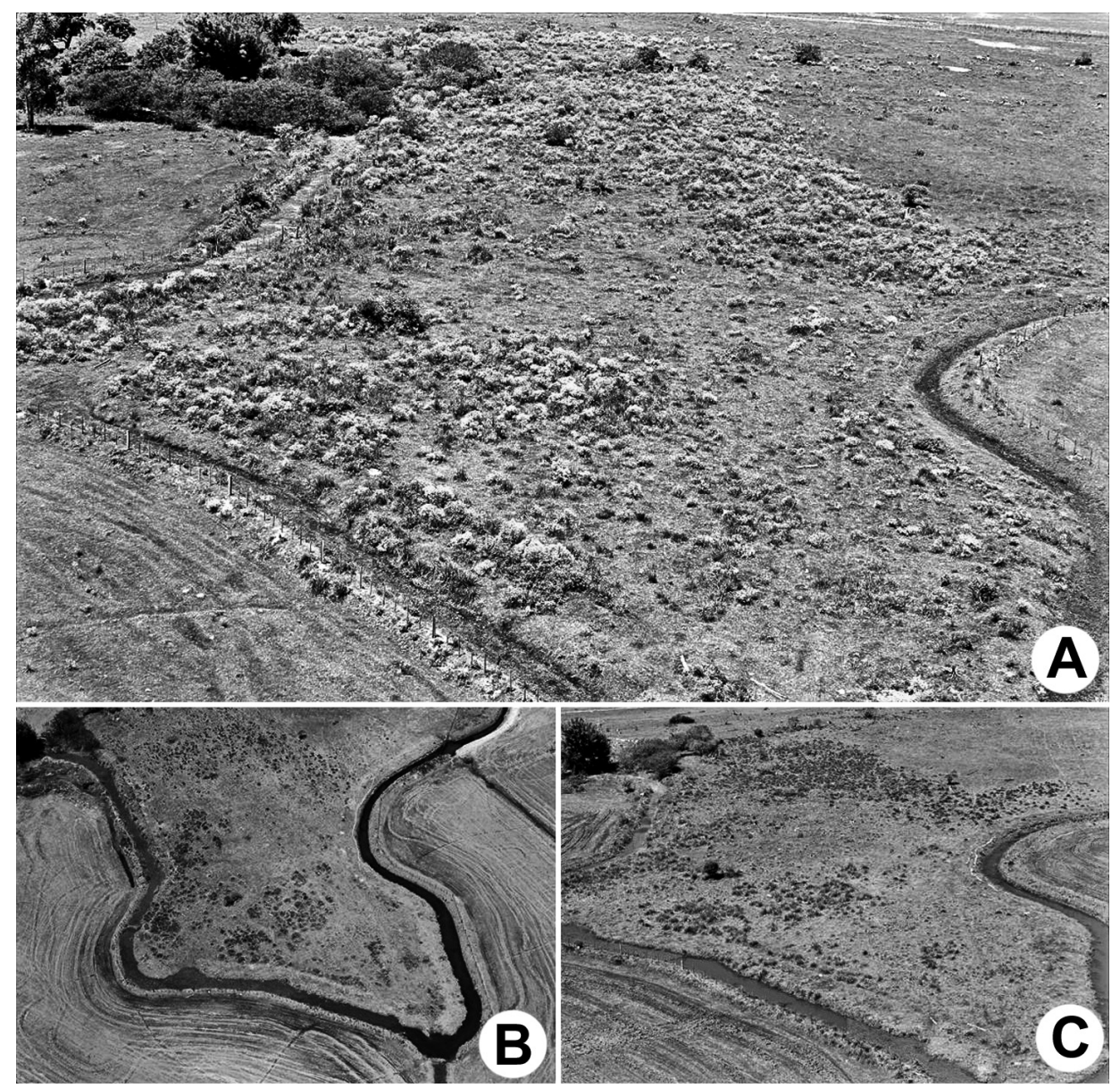

Fig.1. Aerial aspect of the Senecio-infested 5.5 area before introduction of sheep in October 2009. Yellow flowering is from Senecio brasiliensis plants (A). Aerial aspect of the same area in October 2010 (B) and in October 2011 (C).

ep stocking densities were adjusted annually to 3.0 stock units/ ha by removing ewe-lamb pairs in September and by replacing the lambs with ewes in February. Also, rams were kept with ewes from March $1^{\text {st }}$ to April $30^{\text {th }}$, annually. A variable number of mature cattle were introduced and, according to the availability of the pastures, kept in the area. Average cattle stocking practiced in the areas ranged from 0 to 2.7 units/ha.

Liver biopsies were sampled inserting a Menghin needle by right transthoracic approach (Barros et al. 2007). In total, 10 animals (from each species) were sampled before and after the study period. Liver samples were formalin-fixed and routinely processed for histology. A Senecio-infested $2700 \mathrm{~m}^{2}$-area was trimmed in November 2009, but it was kept free from grazing animals to evaluate the emergence and persistence of the Senecio spp. plant. The sheep managed in the Senecio-free area served as controls for the group of sheep that grazed the Senecio-infested area.

\section{RESULTS}

The numbers of the Senecio spp. counting are shown in Table 1. In total, 38,751 Senecio spp. plants were counted before mowing the pastures and before introducing sheep (November 2009) in the infested 5.5-ha area. In September 2009 , two hundred green plants from each species were sampled and weighed. S. madagascariensis and S. brasiliensis plants weighed, on average, 79 and $826 \mathrm{~g}$, respectively. No Senecio plant was found on the 3.6-ha control area. As observed in Table 1 and presumed in Figure 1, in 2010, the persistence of Senecio spp. has been drastically reduced, but by 2011 it was virtually eliminated. The presence of $\mathrm{Se}$ necio species on the side of the fence (opposite the study area) illustrates the control of Senecio exerted by the sheep (Fig.2A).

While Paspalum notatum, Cynodon dactylon, Desmodium intortum, Andropogon lateralis and Axonopus affinis were the dominant pasture species in the 5.5-ha paddock, Eragrostis plana and Eryngium horridum plants also infested some areas. At the end of the study period, the persistence of a few Senecio brasiliensis plants was apparently associated with the protection exerted by the spiny leaves of Eryngium horridum (Fig.2B). The estimates on forage availability ranged from 1,296 to $2,923 \mathrm{~kg} /$ ha (dry matter). Although the sheep remained apparently healthy in the study period, one ewe (haemonchosis) and one lamb (dog attack) died. Five annual cases of digital disease (foot rot) recuperated after being treated for three days with penicillin antibiotics. The sanitary management applied to the sheep is presented in Table 2. No cattle loss was recorded. No lesion characteristic of seneciosis was observed in liver biopsies from sheep or cattle. The data on sheep flock performance are summarized in Table 3; during the study period, no sheep fetal loss could be detected. 

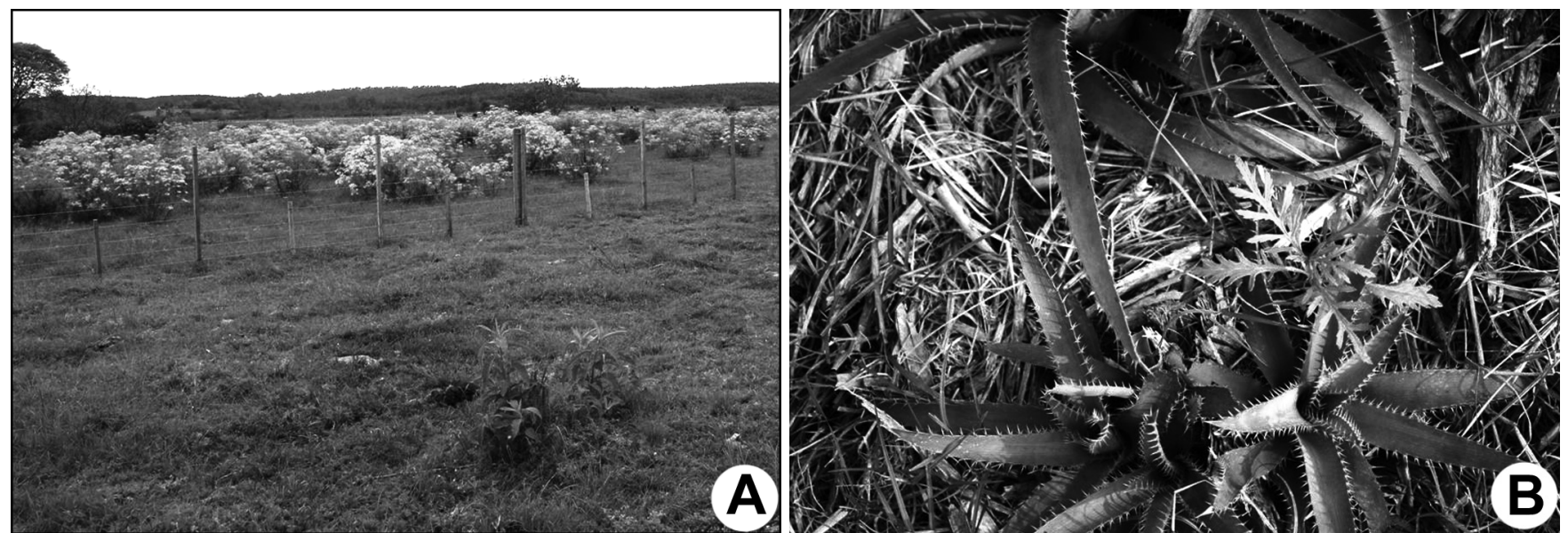

Fig.2. (A) The Senecio brasiliensis populations infesting the contiguous area adjacent to but on the other side of the fence that limits the sheep paddock. (B) Experimental paddock the Senecio brasiliensis seedlings emerging between the spiny leaves of Eryngium horridum, also named 'gravatá'.

Table 2. Sanitary measures applied to the sheep managed in Senecio-free and Senecio-infested areas, November-2009 to November-2011.

\begin{tabular}{lc}
\hline \multicolumn{1}{c}{ Sanitary practices } & 2009-2010-2011 \\
\hline Fenbendazole oral & Nov-Feb-May-Sep \\
Disophenol injectable & Dec-Mar-Jul-Oct \\
Nitroxynil injectable & Jan-Apr-Aug \\
Levamisole oral & Jun \\
Anti-clostridial vaccination & Oct-Jun \\
Fipronil pour on & Dec-Mar-May \\
Myiasis inspection & Daily \\
Clipping & December \\
Claw check and trimming & Bimonthly \\
Formaldeyde spray (digital) & Bimonthly
\end{tabular}

Table 3. Sheep flock performance. November-2009 to November-2011

\begin{tabular}{lcccccc}
\hline & \multicolumn{2}{c}{$\begin{array}{c}\text { Senecio-free } \\
\text { group (11) }\end{array}$} & & \multicolumn{2}{c}{$\begin{array}{c}\text { Senecio-infested } \\
\text { group (16) }\end{array}$} \\
\cline { 2 - 3 } \cline { 6 - 7 } & 2010 & 2011 & & 2010 & 2011 \\
\hline № pregnant ewes (ultrasonography) & 11 & 11 & & 16 & 16 \\
№ lambs born & 13 & 12 & & 19 & 20 \\
Mean birth lamb weight (kg) & 3.5 & 3.7 & & 4.0 & 3.4 \\
Lamb survival (\%) & 100 & 91.7 & & 100 & 100 \\
Mean weight at 5-mo-o 2011 (kg) & 27.1 & 30.1 & & 28.9 & 29.1 \\
Mean daily weight gain (kg) & 0.157 & 0.176 & & 0.166 & 0.171 \\
Mean fleece production (kg) & 3.6 & 2.9 & & 3.6 & 3.0
\end{tabular}

\section{DISCUSSION AND CONCLUSIONS}

In Brazil, as in other countries, poisonous plant control has usually been based on the prevention of overgrazing, the avoidance of placing hungry/thirsty herbivores onto toxic plant-infested pastures, the isolation of infested areas by fence construction, and the elimination of toxic plants by spraying, grubbing, plowing, burning, or mowing (Riet-Correa \& Méndez 2007). Nevertheless, the efficiency of such measures for controlling plant intoxications has been limited and, therefore, efforts have focused on the development of alternative strategies to control the most harmful toxic plants in Brazil, among which Senecio brasiliensis has definitely been included. Much wider role, however, could be attributed to the Senecio madagascariensis control.
In southern Brazil, an association has been suggested between the increased prevalence of bovine seneciosis (Pedroso et al. 2007, Rissi et al. 2007, Lucena et al. 2010) and the decreasing numbers of sheep flocks due to the downturn of the wool market in the late 1980s. A sheep flock of 12,000,000 in 1970 was reduced to approximately $3,500,000$ animals in the 2000 s, a period in which seneciosis became more prevalent and caused increasing losses to the local cattle industry (Riet-Correa \& Méndez 2007, Tokarnia et al. 2012).

The most efficient weed control programs have been those that associate biological techniques with management strategies (Denslow \& Antonio 2005). One of the most striking examples of successful Senecio biological control occurred in Oregon, United States of America, where the populations of Senecio jacobaea were consumed at the control level by the Cinnabar moth of Tyria jacobaeae (Lepidoptera, Arctiidae) (McEvoy et al. 1991). Sheep grazing has long been considered as an applicable measure in weed biological control programs (Huffaker 1968). A cattle-sheep-mixed grazing system has been reported to be an effective Senecio jacobaea-control method (Betteridge et al. 1994). Although sheep might occasionally become affected and die from S. brasiliensis poisoning (Ilha et al. 2001, Grecco et al. 2011), a considerable amount of field observations have indicated that sheep might consume $S$. brasiliensis without suffering any disease. However, information regarding the methodology applicable for this purpose, or on the performance of sheep flocks exposed to Senecio-infested areas, is scarce. A previous report has indicated that sheep continuously stocked at $0.43 /$ hectare control Senecio spp. (Soares et al. 2000).

In this study, a mixed-animal grazing system partially mimicked the traditional extensive exploration system practiced in the native pastures of southern Brazil. While cattle grazed the pastures occasionally, the study focused on sheep management and performance. Cattle were temporarily included in the system for the purpose of keeping the pastures at an adequate height for the sheep's grazing behavior. Especially during the high summer months, the 
cattle have consistently consumed the surplus in the mature pastures present in the area.

As the pastures were trimmed before the introduction of the sheep, the persistence of Senecio plants could only be associated with the budding of existing plants and the germination of seedlings. There could only be a minimal budding of existing $S$. brasiliensis, because its vegetative cycle had ended in late November, and the germination of seedlings in this species in this area occurs mostly from June to August (Karam et al. 2002). However, the S. madagascariensis plants, which are known for their high year-round persistence (Karam et al. 2011), also diminished and were eventually eliminated. S. madagascariensis plants were apparently more easily controlled than the $S$. brasiliensis, as can be interpreted from Table 1. In the study area, the $S$. madagascariensis and $S$. brasiliensis plants infested originally distinct vegetative surroundings. $S$. madagascariensis usually occurred on lower pastures than did S. brasiliensis. Thus, the preference by sheep for grazing those areas or the absence of a protective factor such as that exerted by Eryngium horridum leaves on the $S$. brasiliensis plants might explain why the $S$. madagascariensis plants were more easily controlled. Moreover, the initial total load of $S$. madagascariensis in the infested area was much lower than that of $S$. brasiliensis.

While the initial controlling effect of Senecio plants attributed to mowing cannot be overlooked, a reduction in the Senecio spp. populations (especially when compared to areas without sheep) could be observed soon after the introduction of sheep in the infested area. However, even though both Senecio species studied here showed vulnerability to sheep grazing, in the absence of continued control measures, a gradual re-establishment of the Senecio population is a possibility (Table 1 ). Combined with a prior timely mowing, the sheep grazing system practiced was effective in controlling long-term $S$. brasiliensis and S. madagascariensis populations. The sheep in this study have shown an unconditional preference for grazing both Senecio species, even when there were plentiful pastures. However, the sheep did not appear to show a consistent preference for S. jacobaea (Betteridge et al. 1994). Although the possibility of Senecio consumption by cattle cannot be excluded and since deaths may occur many months after the plant is ingested, no change characteristic of seneciosis was observed in liver biopsies.

Performance was quite similar between sheep from Senecio-free and Senecio-infested areas. Although levels of sheep production higher than those recorded in this study may be observed under specialized sheep systems (Radostits et al. 1994), the reproductive and productive numbers registered in this small group of sheep were comparable to those numbers achieved under a similar traditional management system practiced in southern Brazil (Selaive-Villarroel et al. 1997, Ribeiro et al. 2002, Bonacina et al. 2011). In addition, the weight control of lambs was discontinued after 5 months of age, both because this is a common slaughter age for weaning lambs and also because susceptibility to toxic plants is known to be high in young animals. Although there is little chance of sheep develop seneciosis after ingesting $S$. brasiliensis, sheep liver biopsies didn't show any change that could be associated with the disease. In Brazil, ovine seneciosis has affected sheep kept in severely Senecio-infested areas, in which there was no alternative source of forage (Ilha et al. 2001, Grecco et al. 2011).

Due to the ecological and evolutionary processes of the global weed communities, agricultural lands have experienced a continuous increase in species diversity; this situation requires a continual development of weed control strategies (Mohler 2001). The findings described in this study indicated that sheep flocks are able to produce at acceptable levels of performance when grazing on Senecio-infested areas and are efficient Senecio spp. control tools.

Acknowledgements.- We are grateful to the staff of the Umbu farm for helping in the flock management task, to the Paglioli-Orlandi family for allowing us to develop this study on their farm, and to the professor Djeison Lutier Raymundo (UFL) for his valuable help. This work was financially supported by the Institutos Nacionais de Ciência e Tecnologia (INCT), Conselho Nacional de Desenvolvimento Científico e Tecnológico (CNPq, 573534/2008-0).

\section{REFERENCES}

Barros C.S.L., Castilhos L.M.L., Rissi D.R., Kommers G.D. \& Rech R.R. 2007. Biópsia hepática no diagnóstico da intoxicação por Senecio brasiliensis (Asteraceae) em bovinos. Pesq. Vet. Bras. 27:53-60.

Betteridge K., Costall D.A., Hutching S.M., Devantier B.P. \& Liu Y. 1994. Ragwort (Senecio jacobaea) control by sheep in a hill country bull beef system. Proc. 47 $7^{\text {th }}$ N. Z. Plant Prot. Conf., p.53-57.

Bonacina M.S., Osório M.T., Osório J.C.S., Corrêa G.F. \& Hashimoto J.H. 2011. Influência do sexo e do sistema de terminação de cordeiros Texel x Corriedale na qualidade da carcaça e da carne. Revta Bras. Zootec. 40:12421249.

Cheeke P.R. 1994. A review of the functional and evolutionary roles of the liver in the detoxification of poisonous plants, with special reference to pyrrolizidine alkaloids. Vet. Human Toxicol. 36:240-247.

Cruz C.E.F., Karam F.C., Dalto A.C., Pavarini S.P., Bandarra P.M. \& Driemeier D. 2010. Fireweed (Senecio madagascariensis) poisoning in cattle. Pesq. Vet. Bras. 30:10-12.

Denslow J.S. \& D’Antonio C.M. 2005. After biocontrol: Assessing indirect effects of insect releases. Biol. Cont. 35:307-318.

Gardner D.R., Throne M.S., Molyneaux R.J., Foster J.A. \& Seawright A.A. 2006. Pyrrolizidine alkaloids in Senecio madagascariensis from Australia and Hawaii and assessment of possible livestock poisoning. Biochem. Syst. Ecol. 34:736-744.

Grecco F.B., Silva P.E., Marcolongo-Pereira C., Soares M.P., Collares G. \& Schild A.L. 2011. Seneciose crônica em ovinos no sul do Rio Grande do Sul. Pesq. Vet. Bras. 31:326-330.

Huffaker C.B. 1968. Fundamentos del control biologico de malas hierbas, p.741-760. In: DeBach P. (Ed.), Control Biologico de las Plagas de insectos y Malas hierbas. Compañia Editorial Continental, Buenos Aires.

Ilha M.R.S., Loretti A.P., Barros S.S. \& Barros C.S.L. 2001. Intoxicação espontânea por Senecio brasiliensis (Asteraceae) em ovinos no Rio Grande do Sul. Pesq. Vet. Bras. 21:123-138.

Karam F.S.C., Méndez M.C., Jarenkow J.A. \& Riet-Correa F. 2002. Fenologia de quatro espécies tóxicas de Senecio (Asteraceae) na região Sul do Rio Grande do Sul. Pesq. Vet. Bras. 22:33-39.

Karam F.C., Haraguchi M. \& Gardner D. 2011. Seasonal variation in pyrrolizidine alkaloid concentration and plant development in Senecio madagascariensis Poir. (Asteraceae) in Brazil, p.179-185. In: Riet-Correa F., Pfister J., Schild A.L. \& Wierenga T. (Eds), Poisoning by Plants, Mycotoxins and Related Toxins. CAB International, Wallingford.

Lucena R.B., Pierezan F., Skimmers G.D., Irigoyen L.F., Fighera R.A. \& Barros C.S.L. 2010. Doenças de bovinos no Sul do Brasil: 6706 casos. Pesq. Vet. Bras. 30:428-434. 
Matzenbacher N.I. \& Schneider A.A. 2008. Nota sobre a presença de uma espécie adventícia de Senecio (Asteraceae) no Rio Grande do Sul, Brasil. Revta Bras. Biociênc. 6:111-115.

McEvoy P., Cox C. \& Coombs E. 1991. Successful biological control of ragwort Senecio jacobaeae, by introduced insects in Oregon. Ecol. Appl. 1:430-442.

Mohler C.L. 2001. Weed evolution and community structure, p.44-484. In: Liebman M., Mohler C.L. \& Staver C.P. (Eds), Ecological Management of Agricultural Weeds. Cambridge University Press, Cambridge.

Parsons W.T. \& Cuthbertson E.G. 2001. Fireweed, Senecio madagascariensis Poir., p.304-305. In: Ibid. (Eds), Noxious Weeds of Australia. $2^{\text {nd }}$ ed. CSIRO Publishing, Collingwood, Australia.

Pedroso P.M.O., Pescador C.A.P., Oliveira E.C., Sonne L., Bandarra P.M., Raymundo D.L. \& Driemeier D. 2007. Intoxicações naturais por plantas em ruminantes diagnosticadas no Setor de Patologia Veterinária da UFRGS no período de 1996-2005. Acta Sci. Vet. 35:213-218.

Radostits O.M., Leslie K.E. \& Fetrow J. 1994. Health and Production Management for Sheep, p.527-631. In: Ibid. (Eds), Herd Health. $2^{\text {nd }}$ ed. W.B. Saunders, Philadelphia.

Ribeiro L.A.O., Gregory R.M. \& Mattos R.C. 2002. Prenhez em rebanhos ovinos no Rio Grande do Sul. Ciência Rural 32:637-641.

Riet-Correa F. \& Méndez M.C. 2007. Intoxicações por plantas e micotoxinas, p.99-221. In: Riet-Correa F., Schild A.L., Lemos R.A.A. \& Borges J.R.J. (Eds), Doença de Ruminantes e Eqüídeos. Pallotti, Santa Maria.
Rissi D.R., Rech R.R., Pierezan F., Gabriel A.L., Trost M.E., Brum J.S., Kommers G.C. \& Barros C.S.L. 2007. Intoxicações por plantas e micotoxinas associadas a plantas em bovinos no Rio Grande do Sul: 461 casos. Pesq. Vet. Bras. 27:261-268.

Roux J., Wieczorek A.M., Ramadan M.M. \& Tran C.T. 2006. Resolving the native provenance of invasive fireweed (Senecio madagascariensis Poir.) in the Hawaiian Islands as inferred from phylogenetic analysis. Div. Distrib. 12:694-702.

Scott L.J., Congdon C. \& Playford J. 1998. Molecular evidence that fireweed (Senecio madagascariensis, Asteraceae) is of South African origin. Plant Syst. Evol. 213:251-257.

Selaive-Villarroel A.B., Silveira V.C.P. \& Oliveira N.M. 1997. Desenvolvimento e produção de carnes de ovinos Corriedale abatidos com diferentes idades sobre pastagem natural ou artificial. Revta Agrociênc. 3:111-118.

Soares M.P., Riet-Correa F., Mendes M.C., Rosa F.G. \& Carreira E.G. 2000. Controle biológico de Senecio spp. com pastoreio de ovinos. Segunda Reunión Argentina de Patología Veterinaria, Corrientes, p.79-80. (Resumos)

Tokarnia C.H., Brito M.F., Barbosa J.D., Peixoto P.V. \& Döbereiner J. 2012. Plantas Tóxicas do Brasil, p.98-109. $2^{\text {nd }}$ ed. Editora Helianthus, Rio de Janeiro.

Villalba J. \& Fernández G. 2005. Otra flor amarilla peligrosa: Senecio madagascariensis. Tambo 150:46-48. 